\title{
The Politics of Manipulation: Politeness and Insincerity in the Language of Parasites and Courtesans in Plautus' Comedies
}

\author{
Luis Unceta Gómez
}

In recent years, significant advances have been made in our understanding of linguistic politeness phenomena in Classical languages, especially in Latin. ${ }^{1}$ The analysis of impoliteness has also been addressed, although to a lesser degree. $^{2}$ However, the concept of over-politeness-that is inappropriate, excessive, and/or insistent use of politeness strategies - along with the problem of sincerity in politeness practices, has not been sufficiently explored in Latin, with the exception of Hall's notable approach to latent hypocrisy in certain polite fictions in Cicero's letters. ${ }^{3}$ This study seeks to further explore this issue by examining the comedies of Plautus, specifically, two stock characters from his works, namely the courtesan and the parasite, who make use of certain politeness strategies for manipulative purposes, aiming to control others for their own benefit. In both cases, these characters are known for their disingenuousness in the 'working' sphere, to the extent that their very sustenance might be said to depend on hypocrisy and feigned amiability. 4

If politeness is understood as a 'social lubricant', sincerity may tend to take second priority (in order) to maintain good social relations, ${ }^{5}$ something that was already noted by Goffman (1959). There is a variety of motives for expressing oneself insincerely, and not all lies are antisocial. This is especially observable in compliments, where certain insincere affirmations fulfil a clearly proso-

1 See Unceta Gómez (2018).

2 Iurescia (2019a) offers a complete analysis of the expression of impoliteness in Latin comedy and novel. See also Roesch (2019).

3 Hall (2009: 78-106). See also Unceta Gómez (2019a), on the in/sincerity of certain expressions of happiness as a positive politeness strategy in comedy.

4 I cannot embark here on the complex definition of the concept of 'insincerity'; see Stokke (2014, 2018: esp. 171-198) for a complete analysis.

5 See, for instance, Davidson (2004: 1). According to this author's claims, in 18th century Britain, the concept of hypocrisy was identified with good manners and politeness, becoming an exclusive privilege of the elite, and thus beyond the reach of the servant class. 
cial function. ${ }^{6}$ But there are also certain other insincere statements where the speaker seeks to obtain a benefit at the expense of someone else. The latter will be the focus of my interest here.

Schulze (1984) put forward the manipulative potential of politeness, and Sorlin (2017) has analysed it in detail. The latter questions the altruistic orientation of classical politeness models, such as those by Brown and Levinson $\left({ }^{2} 1987\right)$ and Leech (2014), and suggests the need to consider the speaker's personal motives and goals as well as the perlocutionary effects of his/her speech acts, in order to understand how manipulative discourse can 'parasitise' certain politeness strategies. ${ }^{7}$

At any rate, within a communicative exchange, it is not always easy to draw the line between sincerity and insincerity. From the viewpoint of politeness research, the degree of sincerity may be judged with regard to the propositional content of a specific utterance, or with regard to interest in maintaining good social relations, whereby the prosocial value of certain insincere utterances is justified. $^{8}$

Things are more complicated in the case of ancient languages, where quite a number of fundamental parameters for correctly interpreting im/politeness phenomena are not accessible to us. For example, it is quite likely that insincerity in Latin could be perceived in suprasegmental or non-linguistic features, such as voice pitch or facial expressions: ${ }^{9}$ data that lies outside our reach. We may be sure, however, that these types of perception were possible for Latin speakers, as is confirmed by the lexicalisation of ideas such as 'manipulative amiability', 'adulation' and 'insincere flattery' in verbs like blandiri ${ }^{10}$ 'to behave

6 Talwar et al. (2007). Along these lines, the etymological connection between Spanish semblante (from Catalan semblant) 'facial expression, face, aspect', and Latin simulare 'to put up, pretend, simulate' (derivative of similis 'similar') is also instructive. On compliments in Plautus' comedies, see Unceta Gómez (2019b).

7 Sorlin (2017) defines the limits of the concept of 'manipulation' as follows: 'manipulation could be conceived on a spectrum between persuasion on the one hand and coercion on the other, bearing in mind that manipulation leaning on the side of persuasion would tend to be more belief-based than it is in coercive manipulation. In the latter case, the manipulator would seek to coerce the victims into acting in a certain way (through linguistic/pragmatic — not physical—means) rather than coercing them into adopting the Speaker's beliefs' (Sorlin 2017: 135). On manipulative uses of impoliteness in Plautus, see Iurescia (2016).

8 See, for instance, Pinto (2011: 231).

9 On English, see Fish et al. (2017).

10 According to Barrios-Lech (2016: 120), blanditia should not necessarily be considered a form of manipulation: 'women use the characteristic features of blanditia-amabo and $m i+$ vocative-even when they are not attempting to flatter. [...] blanditia could 
or speak ingratiatingly, flatter', adulare 11 'to flatter in a servile manner, fawn upon', assentari 'to flatter by agreeing', or palpari 'to act in a soothing or cajoling manner', and their corresponding lexical families.

Beyond these linguistic considerations, a few metapragmatic comments offer first-hand information about the in/sincerity of certain obsequious behavioural patterns. The greedy Euclio [1], for instance, thinks he sees a change of attitude in his neighbours after he has found a treasure, though he keeps it hidden: ${ }^{2}$

\section{[1] Plautus Aulularia 182-185}

Meg. saluos atque fortunatus, Euclio, semper sies.

Euc. di te ament, Megadore. Meg. quid tu? recten atque ut uis uales?

Euc. non temerarium est ubi diues blande appellat pauperem. iam illic homo aurum scit me habere, eo me salutat blandius.

Meg. (loudly) May you always be well and blessed, Euclio.

Euc. May the gods love you, Megadorus.

Meg. Well then? Are you in good health, just as you wish?

Euc. (aside) It's not by chance when a rich man addresses a poor one in such an ingratiating way. Now he knows I have the gold, that's why he's greeting me more politely. ${ }^{13}$

But, before going on to address this type of behaviour, certain general concepts about the principles that govern politeness in Latin must be presented.

simply describe a polite way of speaking typically ascribed to women. [...] The word blandus and its cognates have at least two main connotations, "flattering/manipulative" or simply "polite". Nevertheless, as Hall (20og: 80) points out, 'Cicero regularly uses the term blandus and its cognates to refer to language that seems overly effusive and manipulative'.

11 On the etymology of adulare, see Clackson (2017), who, after rejecting the previous proposals, considers it to be a parasynthetic formation originating from a syntagma ad culum, so that, starting from the canine custom of smelling the anus, it would have passed metaphorically to the meaning 'to flatter' (a similar movement is found in English expressions such as arse-licking and brown-nosing).

12 See also Plaut. Aul. 113-117. Pseud. 448-452 offers a reflection on the usefulness of amiability (blandis uerbis). And Most. 181 presents an explicit rejection of insincere praise.

13 Texts and translations are borrowed from the Loeb edition by Wolfgang de Melo (20112013). 
Politeness in Latin includes a whole constellation of different ideas whose common thread is the need to acknowledge oneself, and be acknowledged by others as well, in one's proper social position. Consequently, the linguistic behaviour of each individual in society must follow this pattern. Although social relations are subverted on many occasions in Plautus' comedies—or, perhaps, precisely because of that possibility—-these works may be considered a faithful, comical reflection of a very rigid social structure, where a well-established upper class interacts with characters belonging to the lower class, whether they be slaves or free. In harmony with the Roman sense of uerecundia'14 ('restraint, modesty, deference, respect') the latter must show deference to the former, thereby ensuring and strengthening the status quo. On some occasions, nonetheless, certain underprivileged characters can make use of other linguistic mechanisms to meet their self-serving objectives, on which their livelihood depends.

Within the theoretical framework that I am currently developing for the analysis of politeness phenomena in Latin, ${ }^{15}$ I make use of the difference between politic behaviour ${ }^{16}$ and polite behaviour. ${ }^{17}$ Similarly, following Arundale (2006), I propose substituting the positive/negative politeness dichotomy by another more generic, less ethnocentric opposition, articulated in terms of the concept of connectedness/separateness. ${ }^{18}$ To complete the panorama, along with further studies about impoliteness, consideration must also be given to over-polite behaviour, a negatively marked linguistic behaviour, which is underexplored to date. ${ }^{19}$ In this paper, I will consider 'over-politeness' not only to be an excessive or inappropriate show of politeness but also an insincere, manipulative use of certain strategies. As we will see, with regard to the linguistic habits of the chosen characters, these strategies are primarily mechanisms aiming to

14 Kaster (2005: 13-27).

15 See Unceta Gómez (2019c).

16 I.e. 'linguistic behaviour which is perceived to be appropriate to the social constraints of the ongoing interaction, i.e. as non-salient' (Watts 2003: 19).

17 I.e. 'behaviour beyond what is perceived to be appropriate to the ongoing social interaction, which says nothing about how members evaluate it' (Watts 2003: 21).

18 I'll come back to this model in Section 4. Even if reconceptualised in the light of Arundale's (2006) proposal, for the sake of clarity, throughout this paper I use the terms 'positive/negative politeness' and 'positive/negative face'.

19 See in Culpeper (2011: 100-103) a metapragmatic analysis of over-politeness. Paternoster (2012: 317-321) offers an interesting approach to over-politeness in literary texts. Regarding Latin, Iurescia $(2019 \mathrm{~b})$ presents some reflections on over-politeness as a response to impoliteness; and Konstan (2018) briefly deals with flattery in epic. 
shorten social distance, ${ }^{20}$ not in an effort to avoid conflict or manage social relations, but solely and exclusively in pursuit of one's personal benefit.

\section{$3 \quad$ Selfish Use of Politeness}

In Plautine comedy, there are two character types, the courtesan and the parasite, that share certain traits, such as their limited resources, their lack of social importance and their low hierarchical level. In other words, they share a situation of weakness which makes them dependent and limits their choices and, possibly, a pronounced sexual dimension..$^{21}$ Another very apparent common trait is their linguistic behaviour, characterised by their self-serving use of certain politeness strategies. In the following sections, I will examine how their use of certain manifestations of linguistic politeness becomes a mechanism for trying to manipulate the interlocutor and gain some benefit from him (the characters targeted by this procedure are always men).

\subsection{Parasites}

The parasite appears in eight of Plautus' twenty-one comedies that have survived to our day, ${ }^{22}$ although not all of them adopt this expected prototypical behaviour. ${ }^{23}$ Being a freeman, this character type makes use of his wit as a form of livelihood; ${ }^{24}$ by means of his obsequious behaviour, he tries to be invited to

20 According to Brown and Levinson (21987: $76-77)$, 'D [distance] is a symmetric social dimension of similarity/difference within which S [speaker] \& $\mathrm{H}$ [hearer] stand for the purposes of this act. In many cases (but not all), it is based on an assessment of the frequency of interaction and the kinds of material or non-material goods (including face) exchanged between $\mathrm{S} \& \mathrm{H}$ (or parties representing $\mathrm{S}$ or $\mathrm{H}$, or for whom $\mathrm{S}$ and $\mathrm{H}$ are representatives). An important part of the assessment of $\mathrm{D}$ will usually be measures of social distance based on stable social attributes. The reflex of social closeness is, generally, the reciprocal giving and receiving of positive face'.

21 I.e. if Fontaine (2010: 202, 221-241) is right in his assertion about the Plautine parasite; according to his interpretation, this character is the subject of veiled but substantive jokes that insinuate ongoing paedophiliac relations with their patrons.

22 Damon (1997: 37). On the features of this character and his language, see also Guastella (1988, 2002); Petrone (1989); Maltby (2000); Filoche (2014).

23 For instance, Diabolus in Asinaria or Curculio (Damon 1997: 44). By contrast, slaves, such as Palaestrio in Miles gloriosus (1037-1093, in the context of a trick), can take on certain linguistic habits of a parasite. On the similitudes and differences between Plautus' parasites and those of Greek New Comedy, see Crampon (1988) and Lowe (1989).

24 This characterisation is well developed in their respective monologues (see Maltby 2000; Guastella 2002): Capt. 69-9o, 133-137; Men. 96-103; Persa 53-6o; Stich. 155-195. 
meals in the home of his patron, so as to quiet his proverbial appetite while never being fully satisfied. His insincere nature is well reflected in certain lines from the lost Plautine comedy Colax ('the flatterer'), a Greek loan which this character is known by: ${ }^{25}$

[2] Plautus Colax fr. 2

... qui data fide firmata fidentem fefellerint, subdoli supsentatores, regi ${ }^{26}$ qui sunt proxumi, qui aliter regi dictis dicunt, aliter in animo habent.

Who have deceived the man who trusted them, after giving him their word and vouching for it, the tricky flatterers, who are closest to the king, and who speak words to the king in one sense, but have different intentions on their minds.

A paradigmatic example of this contradiction between the ideas and words of parasites is Artotrogus in Miles gloriosus. He uses a good number of positive politeness strategies in his conversation with his patronus Pyrgopolynices, but, on several occasions, he immediately places these strategies in doubt through asides. We thus find, for example, hyperbolic praise [3], ${ }^{27}$ obvious attempts to avoid conflict through a co-operative attitude and reiterated agreement [4] an example that includes an illustrative aside ${ }^{28}$ —or attention to the needs of the interlocutor, and asserted knowledge of the hearer's needs and concern for them $[5]:{ }^{29}$

25 The colax is a stock character-similar but different from the parasite in Greek literature-which Plautus inherits from Greek New Comedy and seems to gradually do away with, characterising him as a seruus callidus. Fontaine (2010:13) suggests that, in addition to reproducing the Greek $x \dot{\lambda} \lambda \alpha \xi$, colax might be understood, in the Latin speaker's mind, as an - ax formation of the verb colere, which would mean ' "excessively fond of cultivating friendship (with a superior)" and thus "fawning, adulatory, toadying, kowtowing, fulsome, obsequious".'

26 On rex used by parasites as a designation for their patroni, see Crampon (1988: 518-520).

27 An additional example is Mil. 55-6o.

28 See also Mil. 25-30, and a second aside in $33^{-} 35$.

29 The obsequious treatment that the miles receives here is even more obvious, if we compare it to how other characters treat him; see, among others, Mil. 947-99o and Poen. $470-503$. 
[3] Plautus Miles gloriosus 9-12

Pyr. ... sed ubi Artotrogus hic est? Art. stat propter uirum fortem atque fortunatum et forma regia. tum bellatorem Mars haud ausit dicere neque aequiperare suas uirtutes ad tuas.

Pyr. ... But whereabouts is Artotrogus?

Art. He's standing next to a real man, robust, rich and of royal beauty. Mars wouldn't dare to call himself such a warrior or compare his exploits to yours.

[4] Plautus Miles gloriosus 16-24

Art. memini. nempe illum dicis cum armis aureis, quoius tu legiones difflauisti spiritu, quasi uentus folia aut peniculus tectorium.

Pyr. istuc quidem edepol nihil est. Art. nihil hercle hoc quidem est praeut alia dicam ... quae tu numquam feceris. periuriorem hoc hominem si quis uiderit aut gloriarum pleniorem quam illic est, me sibi habeto, ei ego me mancupio dabo; nisi unum, epityra estur insanum bene.

Art. I remember. You mean the one with golden armour of course, whose legions you scattered with a breath as the wind does leaves or a plasterer's brush does plaster.

Pyr. That's a mere nothing.

Art. Indeed, it's a mere nothing compared with other things I might mention ... (aside) which you've never done. If anyone sees a man perjuring himself more than this one or more boastful than he is, he can have me for himself, I'll sell myself to him; but there's one thing: his olive spread tastes awfully good.

[5] Plautus Miles gloriosus 38-41

Pyr. habes- Art. tabellas uis rogare. habeo, et stilum.

Pyr. facete aduortis tuom animum ad animum meum.

Art. nouisse mores tuos me meditate decet curamque adhibere ut praeolat mihi quod tu uelis. 
Pyr. Do you have-

Art. (interrupting) You want to ask me for writing tablets. I do, and a pen.

Pyr. You mind neatly what's on my mind.

Art. I ought to know your ways studiously and take care that I get wind of what you wish in advance.

This amiability, quite obviously excessive, contrasts with the attitude of these characters when they are not assured of getting what they want, ${ }^{30}$ such as in the first meeting between Peniculus and Menaechmus I, who has quarrelled with his wife, thus limiting the possibilities for holding a banquet in his home:

[6] Plautus Menaechmi 143-151

Men. dic mi, enumquam tu uidisti tabulam pictam in pariete ubi aquila Catamitum raperet aut ubi Venus Adoneum?

Pen. saepe. sed quid istae picturae ad me attinent? Men. age me aspice.

ecquid assimulo similiter? Pen. qui istic ornatust tuos?

Men. dic hominem lepidissimum esse me. Pen. ubi esuri sumus?

Men. dic modo hoc quod ego te iubeo. Pen. dico: homo lepidissume.

Men. ecquid audes de tuo istuc addere? Pen. atque hilarussime.

Men. perge, $\langle$ perge $\rangle$. Pen. non pergo hercle nisi scio qua gratia. litigium tibi est cum uxore, eo mi aps te caueo cautius.

Men. Tell me, have you ever seen a mural painting where an eagle carries off Ganymede or Venus carries off Adonis?

Pen. Often. But what do those pictures have to do with me?

Men. Go on, look at me. Do I resemble them in a similar way?

Pen. (noticing the mantle) What are you dressed up for like that?

Men. Say that I'm a jolly good fellow.

Pen. Where are we going to eat?

Men. Just say what I'm telling you.

Pen. All right: jolly good fellow.

Men. Do you want to add something of your own to it?

Pen. And jolly charming fellow.

Men. Go on, go on!

30 See, for instance, the impoliteness of the parasite in Bacch. $577-583$. 
Pen. I'm not going, unless I know what for. You're having a quarrel with your wife, that's why I'm taking extra-careful care for myself against trouble from you.

Significantly, Peniculus' attitude changes immediately after Menaechmus I communicates his intention to celebrate a banquet without his wife knowing (Men. 162).

The self-serving nature of parasites is revealed even in the most delicate moments, such as in Captiui, when Ergasilus expresses his empathy to Hegio on the disappearance of his son [7]. The parasite makes his appearance by sobbing and expresses his condolences, in heartfelt fashion, winning Hegio's approval (laudo) even though the parasite explicitly expresses disagreement with him (something that is justified by the context and which contributes to the polite fiction). However, as is revealed immediately, it is all done in self-interest; the true pain is what is brought on by his hunger:

[7] Plautus Captiui 139-141, 146-153

Heg. ne fle. Erg. egone illum non fleam? egon non defleam talem adulescentem? Heg. semper sensi filio meo te esse amicum et illum intellexi tibi.

$[\ldots]$

Heg. alienus quom eius incommodum tam aegre feras, quid me patrem par facere est, quoi ille est unicus?

Erg. alienus? ego alienus illi? aha, Hegio, numquam istuc dixis neque animum induxis tuom; tibi ille unicust, mi etiam unico magis unicus.

Heg. laudo, malum quom amici tuom ducis malum. nunc habe bonum animum. Erg. eheu, huic illud dolet, quia nunc remissus est edendi exercitus.

Heg. Stop crying.

Erg. Should I not cry for him? Should I not weep without restraint for such a man?

Heg. I always felt that you were close to my son and I saw that he was close to you. [...]

Heg. Since you as an outsider find it so hard to bear his misfortune, what must I as his father do, for whom he is the only son?

Erg. Outsider? I an outsider to him? No, no, Hegio, never say that, and never believe that. To you he's the only one, but to me he's even more of an only one than an only one. (starts crying again) 
Heg. I praise you for considering a friend's misfortune to be your own misfortune. Now take heart.

Erg. Oh, oh, oh, this one (pointing to his stomach) is in pain about the eating force having been dismissed now.

Expressions of commiseration, as well as congratulations, are required speech acts in certain situations, thus absolute sincerity cannot be assumed in every case. ${ }^{31}$ On this occasion, however, the speech acts seek a result that goes beyond the mere expression of sympathy for the interlocutor's problems or suffering, and Ergasilus ends up by explicitly requesting an invitation to dinner. ${ }^{32}$

The parasite's manipulative disposition is especially noticeable when his strategies do not attain their desired objective. This happens with Gelasimus, the parasite in Stichus. After a long journey abroad, his patron Epignomus returns home with great wealth and an entourage of parasites who threaten to displace him. When Gelasimus first encounters his patron [8], his greeting conveys a highly exaggerated expression of happiness, quite conventionalised in this speech act, ${ }^{33}$ as well as his good wishes. Despite the grandiose expression, Epignomus looks favourably upon the parasite's words as is seen in his metapragmatic comment, where he extends his appreciation:

[8] Plautus Stichus 465-469

Gel. ... Epignome, ut ego nunc te conspicio lubens! ut prae laetitia lacrumae prosiliunt mihi! ualuistin usque? Epi. sustentatum est sedulo.

Gel. propino tibi salutem plenis ... faucibus.

Epi. bene atque amice dicis. di dent quae uelis.

31 Leech (2014: 212). On congratulations in Roman comedy, see Unceta Gómez (2016).

32 Erg. quia mi est natalis dies; propterea $\langle a\rangle$ te uocari ad te ad cenam uolo (Capt. 174-175) 'Erg. Because it's my birthday. That's why I want to be invited by you to a dinner at your place'. Similarly, when he conveys to Hegio the good news of his son's arrival, his main objective is to be invited to a sumptuous dinner (Capt. 780). At the moment when he shares the news, being fully assured of the reward it will bring him, he goes so far as to make formulations that clearly threaten the addressee's negative face, as in: Heg. Iuppiter te dique perdant. Erg. te hercle ... mi aequom est gratias agere ob nuntium (Capt. 868-869) 'Heg. May Jupiter and the gods destroy you. Erg. No, you ... should thank me for my message'.

Berger (2016); Unceta Gómez (2019a). 
Gel. ... (loudly) Epignomus, how happy I am to see you now! How my tears are gushing forth out of joy! Have you been well throughout?

Epi. I've taken good care of myself.

Gel. I'm drinking to your health with a full ... gullet.

Epi. It's kind and friendly of you to say so. May the gods grant what you wish.

The parasite's next move is clearly an affiliative act (in Hall's [2009] terminology): the invitation to dine at his house [9] and the completely unbelievable gesture, given the proverbial poverty of parasites. Epignomus politely rejects the invitation, offering excuses, ${ }^{34}$ but Gelasimus insists no less than eight times; such insistence is clearly inappropriate and may even be considered impolite, but Epignomus replies by presenting several reasons:

[9] Plautus Stichus 471-482

Epi. cenem illi apud te? Gel. quoniam saluos aduenis.

Epi. locata est opera nunc quidem; tam gratia est.

Gel. promitte. Epi. certum est. Gel. sic face inquam. Epi. certa rest.

Gel. lubente me hercle facies. Epi. idem ego istuc scio. quando usus ueniet, fiet. Gel. nunc ergo usus est.

Epi. non edepol possum. Gel. quid grauare? censeas. nescioquid uero habeo in mundo. Epi. i modo, alium conuiuam quaerito tibi in hunc diem.

Gel. quin tu promittis? Epi. non grauer si possiem.

Gel. unum quidem hercle certo promitto tibi: lubens accipiam certo, si promiseris.

Epi. ualeas. Gel. certumne est? Epi. certum. cenabo domi.

Epi. I should dine there at your place?

Gel. Since you've arrived safely.

Epi. My services are engaged at present; much obliged to you all the same.

Gel. Promise.

Epi. I'm resolved.

Gel. Do, I insist.

34 On this politeness strategy in Latin, see Ferri (2012: 133-134). 
Epi. It's settled.

Gel. You'll really do me a pleasure.

Epi. That I know too. When the need arises, it'll be done.

Gel. Then there's need now.

Epi. I really can't.

Gel. Why are you objecting? Reconsider it. Seriously, I have something in store for you.

Epi. Just go, find yourself another table companion for today.

Gel. Why don't you promise?

Epi. I wouldn't object if I could.

Gel. One thing I promise for certain: I'll accept with pleasure for certain, if you promise.

Epi. Goodbye.

Gel. Are you resolved?

Epi. Yes, I am resolved. I'll dine at home.

The objective, revealed immediately afterwards, is to get an invitation to dine. An explicit request follows, to which Epignomus replies again by giving excuses, and the parasite insists, while clearly threatening the negative face of his interlocutor (483-496).

According to Barrios-Lech, ${ }^{35}$ the parasite, along with the adulescens, are the male character types who 'speak most politely'; his quantitative data shows that this character typically makes use of softening hedges (almost three times as much as the senes, adulescentes and serui altogether); ${ }^{36}$ and of the pragmatic marker obsecro (second only to the adulescentes). ${ }^{37}$ In both cases, these mechanisms can contribute to the expression of negative politeness, where parasites underscore their position as inferior and dependent on the favours of others. More than these elements, however, the really unique aspect of their language is the abundant use of positive politeness strategies, whereby they show such familiarity toward their patrons that it may be considered excessive. In this strategy, parasites clearly go beyond appropriate, politic behaviour; their intensification of polite strategies is often judged negatively (whether by the addressee, the bystanders, or the audience).

35 Barrios-Lech (2016: 48).

36 Barrios-Lech (2016: 150).

37 Barrios-Lech (2016: 124-125 and Table 9·3). 


\subsection{Meretrices}

The second character that interests us here, with an even greater presence in the Plautine comedies, is the courtesan, who also uses politeness in selfinterest. Barrios-Lech's distinction between meretrix and pseudo-meretrixthe latter has freeborn status and is more careful and 'polite' in her speech ${ }^{38}$-is helpful in determining certain interesting deviations, but it will not be taken into account in this analysis of over-polite strategies, which are used by both character types. ${ }^{39}$

The self-serving character of the meretrices is evidenced on numerous occasions, such as in the well-known passage that compares prostitution to the occupation of fowlers:

[10] Plautus Asinaria 215-223

non tu scis? hic noster quaestus aucupi simillimust. auceps quando concinnauit aream, offundit cibum; [aues] assuescunt: necesse est facere sumptum qui quaerit lucrum; saepe edunt: semel si captae sunt, rem soluont aucupi. itidem hic apud nos: aedes nobis area est, auceps sum ego, esca est meretrix, lectus illex est, amatores aues; bene salutando consuescunt, compellando blanditer, osculando, oratione uinnula, uenustula.

Don't you know? This trade of ours is very similar to catching birds. When a fowler prepares a clearing, he spreads food there; they get used to it. He who seeks profit must make an investment. They eat often; but once they're caught they give the fowler his reward. It's the same at our place here: our house is our clearing, I'm the fowler, the prostitute is the bait, the bed is the decoy, and the lovers are the birds. They get used to us through nice greetings, sweet addresses, kissing, tender and delightful speech.

This amiability is used exclusively when there is some profit in sight, ${ }^{40}$ e.g. as Diabolus reproaches Cleareta in Asinaria [11]:41

$3^{8}$ See Barrios-Lech (2016: 123, 150, 269).

39 Similarly, even in cases where we can determine that the courtesan is truly in love, they make use of exaggerated expressiveness, as can be noted, for instance, with Lemniselene, the courtesan in Persa (cf. e.g. 766).

40 When possibilities for obtaining such a profit disappear, courtesans can become curt or even impolite, as, for instance, in Poen. 330-409.

Diniarchus in Truculentus (22-73) also complains about the behaviour of courtesans and 
[11] Plautus Asinaria 204-206, 208, 210-214

aliam nunc mi orationem despoliato praedicas, longe aliam, inquam, 〈iniqua $\rangle$, praebes nunc atque olim quom dabam, aliam atque olim quom illiciebas me ad te blande ac benedice.

$[\ldots]$

me unice unum ex omnibus te atque illam amare aibas mihi:

$[\ldots]$

meo de studio studia erant uostra omnia, usque adhaerebatis: quod ego iusseram, quod uolueram faciebatis, quod nolebam ac uotueram, de industria fugiebatis, nec conari id facere audebatis prius. nunc nec quid uelim nec nolim facitis magni, pessumae.

Now that you've robbed me you are using a different kind of rhetoric on me; I say, now you give me a kind of rhetoric far different from when I was providing for you, you criminal, different from the time when you were enticing me to you with flattery and kind words. [...] You used to say to me that out of all people you and she loved me and me only; [...] all your interests were in line with mine, you were clinging on to me all the time. You did whatever I ordered and whatever I wished, you deliberately avoided whatever I didn't wish and forbade, and you didn't dare try this earlier. Now you don't give a damn about what I like and what I dislike, you crooks.

This obsequious behaviour, whereby the meretrices are distinguished from the matrons, ${ }^{42}$ is usually directed toward lovers from whom there is hope of a profit. ${ }^{43}$ This is seen, for example, in Menaechmi, where the courtesan Erotium displays all of her charm (by the means of mechanisms such as the use of $m i+$ vocative, which is a term of affection, ${ }^{44}$ a form of affiliation, expres-

describes their manner in detail. See also his reproaches to Astaphium, servant of his beloved Phronesium (Truc. 162-163).

42 Cleo. non matronarum officiumst, sed meretricium, uiris alienis, mi uir, subblandirier (Cas. 585-586) 'Cleo. My dear husband, it's not the job of wives, but of prostitutes, to charm other men'.

Even so, use of these techniques is also confirmed outside the business exchange with one's client, as in Bacch. 39-100, where Bacchides, paradigm of the 'bad meretrix', manages to win the favour of Pistoclerus and overcomes his efforts to resist (50 uiscus merus uostra est blanditia; 'Your flattery is pure birdlime'). See also Rud. $435^{-438 .}$ 
sion of agreement, exaggerated sympathy and approval), in order to win her client's favour; this sharply contrasts with how she treats the slave of Menaechmus I, Peniculus, who makes a metapragmatic comment on the courtesan's attitude:

[12] Plautus Menaechmi 182-186, 190-193

Ero. anime mi, Menaechme, salue. Pen. quid ego? Ero. extra numerum es mihi.

Pen. idem istuc aliis ascriptiuis fieri ad legionem solet.

Men. ego istic mihi hodie apparari iussi apud te proelium.

Ero. hodie id fiet. Men. in eo uterque proelio potabimus;

$[\ldots]$

Pen. interim nequis quin eius aliquid indutus sies.

Ero. quid hoc est? Men. induuiae tuae atque uxoris exuuiae, rosa.

Ero. superas facile ut superior sis mihi quam quisquam qui impetrant.

Pen. meretrix tantisper blanditur, dum illud quod rapiat uidet.

Ero. My sweetheart, Menaechmus, hello.

Pen. What about me?

Ero. You don't count to me.

Pen. That same thing is always said to happen to supernumeraries like me in the army too.

Men. (to Erotium) I ordered that a battle should be prepared for myself here at your place today.

Ero. It shall take place today.

Men. In this battle we shall both drink. [...]

Pen. (aside) In the meantime you can't help wearing something of hers.

Ero. What is this? (points to the mantle)

Men. You are robed and my wife is robbed, my rose.

Ero. You easily gain the upper hand so that for me you are above any of those who command me.

Pen. A prostitute only flatters as long as she can see something she can snatch.

tion for strengthening a petition. See also the comical imitation of this resource in Cas. 134-138. 
In this same scene [13], there are other typical procedures of positive politeness: expression of agreement, attention to the interests and needs of the hearer, and even anticipation of these:

[13] Plautus Menaechmi 207-209, 213-215

Men. scin quid ${ }^{45}$ uolo ego te accurare? Ero. scio, curabo quae uoles.

Men. iube igitur tribus nobis apud te prandium accurarier atque aliquid scitamentorum de foro opsonarier, $[\ldots]$ atque actutum. Ero. licet ecastor. Men. nos prodimus ad forum. iam hic nos erimus: dum coquetur, interim potabimus.

Ero. quando uis ueni, parata res erit. Men. propera modo.

Men. (to Erotium) Do you know what I want you to take care of?

Ero. I know, I'll take care of what you want.

Men. Then have a lunch prepared at your place for the three of us, and have some delicacies brought from the market [...] and at once.

Ero. Yes, of course.

Men. We're off to the forum. We'll be back soon. While it's being cooked, we'll drink.

Ero. Come when you wish, it will be ready.

Men. Just hurry.

The intensification of familiarity produced by these expressive mechanisms becomes entirely evident when they are used with a stranger, as occurs in the comical recourse of twins in the same comedy: ${ }^{46}$

[14] Plautus Menaechmi 361-374

Ero. ... animule mi, mi mira uidentur

45 As Barrios-Lech (2016: 215-218) has noted, the pattern scin quid ...? allows courtesans to anticipate the client's wishes. The expression-which is not a real request for information but has the communicative function of getting the interlocutor's attention and leading up to a request-is treated literally by the courtesans, thereby intensifying the impression of interest toward their clients.

46 See also Men. 207-212, 677; Bacch. 1178-1179; Mil. 1161-1163. 
te hic stare foris, fores quoi pateant,

magis quam domus tua domus quom haec tua sit.

omne paratum est, ut iussisti

atque ut uoluisti, [...].

prandium, ut iussisti, hic curatum est:

ubi lubet, ire licet accubitum.

Sos. quicum haec mulier loquitur? Ero. equidem tecum. Sos. quid mecum tibi

fuit umquam aut nunc est negoti? Ero. quia pol te unum ex omnibus

Venus me uoluit magnuficare, neque id haud immerito tuo.

nam ecastor solus benefactis tuis me florentem facis.

Sos. certo haec mulier aut insana aut ebria est, Messenio, quae hominem ignotum compellet me tam familiariter.

Ero. ... My sweetheart, it seems strange to me that you're standing outside here: the door stands open for you, since this house is more yours than your own house is. Everything is prepared, as you ordered and as you wanted. [...] The lunch has been seen to, as you told me. We can go and recline at table as soon as you wish.

Sos. (to Messenio) Who is this woman talking to?

Ero. To you of course.

Sos. What business have I ever had with you or have I now?

Ero. Because out of all men Venus wanted me to hold you alone in esteem, and not undeservedly so: you alone let me flourish through your generosity.

Sos. (again to Messenio) This woman is definitely either mad or drunk, Messenio: she addresses me, a total stranger, so intimately.

The effect is quite comical, even ridiculous, since Sosicles does not know this woman. Intensification of closeness (when the distance between two strangers is great) is entirely improper despite Erotium emphasising her subsidiary position using, for instance, the verb iussisti.

In the case of [15], however, Stephanium, the courtesan of Stichus, addresses two fellow slaves. Even though the relationship is therefore different from the previous ones, there is nevertheless a great similarity between Stephanium's expressive resources and those we have seen on other occasions, e.g. apologies for lateness, interest in the hearer's wishes and expressions of affection: 
[15] Plautus Stichus 742-744, 750-753

Ste. morigerabor, meae deliciae. nam ita me Venus amoena amet, ut ego huc iam dudum simitu exissem uobiscum foras, nisi me uobis exornarem. nam ita est ingenium muliebre:

$[\ldots]$

Ste. utrubi accumbo? Sang. utrubi tu uis? Ste. cum ambobus uolo, nam ambos amo.

Sti. uapulat peculium, actum est. Sang. fugit hoc libertas caput.

Ste. date mi locum ubi accumbam, amabo, siquidem placeo. Sti. tun mihi?

Ste. cupio cum utroque. Sti. ei mihi! bene dispereo.

Ste. I'll humour you, my darlings: as truly as lovely Venus may love me, I'd have come out here together with you long ago, if I hadn't been making myself pretty for you; yes, a woman's nature is like this [...] In which place am I to recline?

Sang. In which do you want to?

Ste. I want to be with both, because I love you both.

Sti. My savings are getting a thrashing, I'm done for.

Sang. Freedom is running away from me.

Ste. Please, give me a place to recline, you two, if you like me.

Sti. I like you?

Ste. I wish to do so with each of you.

Sti. Dear me! I'm perishing in a good way.

In this case, we also see the use of a frequent form of blanditia and the pragmatic marker amabo, used mostly in combination with requests or questions. ${ }^{47}$ A characteristic element of the female sociolect and strongly associated with an erotic context, ${ }^{48}$ amabo is used mainly by courtesans ${ }^{49}$ and is also a trait that strikingly differentiates their language from that of pseudo-courtesans; according to the statistical data presented by Barrios-Lech, 'courtesans direct

\footnotetext{
47 But it is not an exclusive function: on the uses of this pragmatic marker, see Unceta Gómez (2015) and Fedriani (2017).

48 In five of the seven examples in Plautus in which it is pronounced by a man, it is addressed to a woman in an amorous context; the other two appear in a homoerotic context.

49 Courtesans use amabo almost five times more than matrons do, and, in Terence, only courtesans use amabo (Barrios-Lech 2016: 121-123 and Table 9.2). The reason for this, as Barrios-Lech (2016: 123) indicates, would have to be found in the ideology of the 'good wife', 'whose public conduct should be characterized by restraint'.
} 
two-thirds of all tokens of amabo put in their mouths to lovers. But the pseudocourtesan directs to a lover only one-fifth of the total tokens of amabo assigned to her. 50

Phronesium's behaviour in Truculentus is also rather interesting. After denying her professional favours to Diniarchus, she becomes agreeable towards him, be it in a strange type of relationship that might be considered as 'friendship' (see 434-440), although Phronesium continues to ask him for a gift (425-427). In [16], we can identify: the pragmatic marker amabo, a joke, flattery, the offer of a kiss, and an invitation to dine-in other words, an intensification of interest in the boy: ${ }^{51}$

[16] Plautus Truculentus 352-353, 355-356, 358-363

Phro. num tibi nam, amabo, ianua est mordax mea, quo intro ire metuas, mea uoluptas?

$[\ldots]$

Phro. quid tam inficetu's Lemno adueniens qui tuae non des amicae, Diniarche, sauium?

$[\ldots]$

Din. salua sis, Phronesium.

Phro. salue. hicine hodie cenas, saluos quom aduenis?

Din. promisi. Phro. ubi cenabis? Din. ubi tu iusseris.

Phro. hic; me lubente facies. Din. edepol me magis. nemp' tu eris hodie mecum, mea Phronesium?

Phro. uelim, si fieri possit.

Phro. Please, my darling, you don't think my door will bite you, do you, so that you should be afraid to go in? [...] Why are you so unmannered that on your arrival from Lemnos you won't give your girlfriend a kiss, Diniarchus? [...]

Din. My greetings, Phronesium.

Phro. And mine to you. Won't you have dinner here today, since you've arrived safely?

Din. I have a prior engagement.

$50 \quad$ Barrios-Lech (2016: 123).

51 This behaviour sharply contrasts with how she treats the soldier Stratophanes (Truc. 499542 ), from whom she seeks to obtain a nice profit. And the attitude of Diniarchus himself is also different than how he will act slightly later, when he wants to recover the child that he has lent to Phronesium in order to pull off a trick on the soldier (Truc. 86o-861). 
Phro. Where are you going to have dinner?

Din. Where you tell me to.

Phro. Here; you'll do me a pleasure.

Din. Myself even more. You'll be with me today, won't you, my dear Phronesium?

Phro. I'd love to, if it were possible.

Finally, the most expressive representation of this behaviour is found in Miles gloriosus, where Acroteleutium makes use of a further resource: intensifying the emotional element and simulating extreme lovesickness, including a fictitious faint, ${ }^{52}$ trembling, and a suicide threat. ${ }^{53}$

By the means of the preceding examples, we can appreciate the richness of manifestations of blanditia, the typical over-politeness of courtesans, as a form of manipulation that is primarily, though not exclusively, female. ${ }^{54}$

\section{Discussion and Conclusions}

Although most of the linguistic resources that have, thus far, been recognised as mechanisms of manipulation can also be found in the speech of other character types, it seems evident that both courtesans and parasites are the stock characters that most often draw on a battery of procedures for giving positive face to the persons whom they depend on for their own livelihood. Among the positive politeness strategies inventoried by Brown and Levinson, ${ }^{55}$ Table 1 presents those that are most easily recognised in the examples analysed in this paper. This table does not contend on being exhaustive, but merely indicative. However, one may note that certain passages are overloaded with this type of strategies.

Furthermore, at the expressive level, we see some consistency in the frequent use of flattery, and, in the case of courtesans, of affectionate terms,

52 The same stratagem is employed by the other courtesan in this comedy, Philocomasium (Mil. 1330-1332).

53 See Mil. 1239-1241, 126o-1261, 1272-1273. On this stereotype of lovers, see Dutsch (2012).

54 Cf. supra, n. 10. As Dutsch (2008: 75-77) notes, the man can be influenced by the prostitute and become a blandus amator, a type of behaviour that is completely unsuitable outside of the female sphere. 'Plautus routinely casts the vir blandiens in the following scenario: in order to satisfy his lust, the lover needs someone else's help and, in order to obtain it, adopts a woman's persuasive manner of speaking (blanditia)' (Dutsch 2008: 77). See Plaut., Trin. 245-247 and Cist. 449-46o.

55 Brown and Levinson ( ${ }^{2} 1987$ : 101-129). 


$\begin{array}{lll}\text { Positive politeness strategy } \quad \text { Parasites Courtesans } & \end{array}$

\begin{tabular}{|c|c|c|}
\hline $\begin{array}{l}\text { Notice, attend to } \mathrm{H} \text { (interests, wants, needs, } \\
\text { goods) }\end{array}$ & {$[6]$} & {$[12],[13],[14],[15],[16]$} \\
\hline $\begin{array}{l}\text { Exaggerate (interest, approval, sympathy } \\
\text { with } \mathrm{H})\end{array}$ & {$[3],[4],[7],[8]$} & {$[12],[14],[15]$} \\
\hline Seek agreement & {$[4]$} & {$[12],[13]$} \\
\hline Avoid disagreement & [4] & {$[14],[15]$} \\
\hline Presuppose/raise/assert common ground & [7] & \\
\hline Joke & & {$[16]$} \\
\hline $\begin{array}{l}\text { Assert or presuppose S's knowledge of and } \\
\text { concern for H's wants }\end{array}$ & {$[5]$} & {$[12],[13]$} \\
\hline Offer, promise & [9] & {$[12],[13],[15],[16]$} \\
\hline Give (or ask for) reasons & & {$[15]$} \\
\hline $\begin{array}{l}\text { Give gifts to } \mathrm{H} \text { (goods, sympathy, under- } \\
\text { standing, co-operation) }\end{array}$ & [8] & {$[16]$} \\
\hline
\end{tabular}

diminutives, the possessive $m i$ + vocative, and the pragmatic marker amabo. All these strategies seek to create a fiction on familiarity with the addressee.

Despite the occasional explicit expression of their position of dependence and submission, the most frequent attitude in parasiti and meretrices is that of attempting to reduce social distance with their addressee. It is to this end that they apply all these strategies of connectedness. ${ }^{56}$ This sharply contrasts with the acceptable politic behaviour for the lower classes (and even with the polite behaviour that behoves them), that is, with adopting a humble attitude and manifesting the social distance and hierarchical superiority of their interlocutor. The communicative style of these characters may, therefore, be considered unconventional, in that it is excessive and fails to follow the prevailing norm in Latin, something that is not justifiable even by the acquaintance that can be observed in most of the cases that were analysed. It can also be added that, outside of Plautine comedy, the same overlap exists between more or less sincere affiliative techniques and expressions typical of contexts of familiarity, as Hall has noted in Cicero's letters. ${ }^{57}$

$5^{6} \quad$ Brown and Levinson $\left({ }^{2} 1987: 103\right)$ consider positive politeness as a 'social accelerator'.

57 'The language, then, of affiliative politeness and blanditiae overlapped to a considerable degree. Both aimed at suggesting a sense of solidarity and familiarity with the addressee, 
Beyond that, these mechanisms are clearly conscious ones (not automated or routinised) and insincere; their effectiveness lies in constituting a nonstandard procedure to please the elite, an expectation that comedies discussed here may seek to ridicule. Moreover, the procedure brings about interesting comical effects, given that everyone (bystanders and audience) can see that such dealings are over-polite-being excessive and insincere at once-except for the addressees, who are fooled in most cases. ${ }^{58}$

The manipulative intent and self-serving nature of these forms of politeness are assured by the fact that the beneficiary of these strategies is always ultimately the one who utters them, not their recipient, who usually falls prey to the insincerity. Hall also reaches this conclusion and points to the difficulties faced by modern scholars in determining a manipulative intent in certain practices. ${ }^{59}$ In comedy, however, the plotlines allow us to determine the perlocutionary effect of these acts. The contextual information provides an external portrayal of the different characters' conduct and communicative styles. This is precisely why theatre constitutes an unsurpassed corpus with which one may test theories about pragmatics and linguistic politeness.

The analysis of communities of practice, ${ }^{60}$ such as those of prostitutes and parasites, with their characteristic linguistic behaviours, allows a glimpse into some Roman conceptualisations regarding the need to uphold politeness within reasonable limits and under a certain degree of control. The elite is-or should at least be-alien to any expressive excesses. In this way, the four-sided model proposed in Unceta Gómez (2019c) can be expanded with the inclusion of the notion of over-politeness (Table 2). ${ }^{61}$

often through the use of compliments and overstatement. The more conventionalized strategies, however, make these claims in a relatively restrained way that takes care to show respect to the addressee. blanditiae, by contrast, seem to be characterized in part by bolder assumptions of familiarity and intimacy, conveyed by the use of less formal idioms' (Hall 2009: 82).

58 See, for instance, the words of Diniarchus, the adulescens who is in love with Phronesium in Truculentus and who acknowledges the gullibility of lovers (Truc. 190-192).

59 'Their language is often similar and both often involve fictions; the difference lies largely in who benefits. If these fictions help to save the addressee's face and to promote mutually beneficial social harmony, they are likely to be viewed favorably. But if the writer seems to be angling for some advantage of his own, these civilities take on a rather more suspect character' (Hall 2009: 99).

6o That is, 'a loosely defined group of people who are mutually engaged on a particular task' (Mills 2003: 30).

61 Interestingly, the Handbook of Electioneering offers an indication that allows to interpret blanditia as a distorted form of comitas: deinde id quod natura non habes induc in animum ita simulandum esse ut natura facere uideare. nam comitas tibi non deest, ea quae 
TABLE 2 Politeness system in Latin

\begin{tabular}{llll}
\hline & $\begin{array}{l}\text { Politic } \\
\text { decorum }\end{array}$ & $\begin{array}{l}\text { Polite } \\
\text { honorificentia }\end{array}$ & $\begin{array}{l}\text { Over-polite } \\
?\end{array}$ \\
\hline Connection & Affiliation & Intensification of closeness & $\begin{array}{l}\text { Excessive intensification of } \\
\text { closeness } \\
\text { Separation }\end{array}$ \\
& Deference & Redress & comitas \\
& uerecundia, & modestia, humilitas & \\
& humilitas & & \\
& & &
\end{tabular}

\section{Acknowledgements}

Many thanks are due to the editors of this volume, Gunther Martin, Federica Iurescia, Severin Hof, and Giada Sorrentino, for their helpful comments and feedback. Any remaining infelicities are entirely my own.

\section{References}

Arundale, R.B., (2006), 'Face as Relational and Interactional: a Communication Framework for Research on Face, Facework, and Politeness', Journal of Politeness Research 2, 193-216.

Barrios-Lech, P., (2016), Linguistic Interaction in Roman Comedy, Cambridge.

bono ac suaui homine digna est, sed opus est magno opere blanditia, quae etiamsi uitiosa est et turpis in cetera uita, tamen in petitione est necessaria. etenim cum deteriorem aliquem adsentando facit, tum improba est, cum amiciorem, non tam uituperanda, petitori uero necessaria est, cuius frons et uultus et sermo ad eorum quoscumque conuenerit sensum et uoluntatem commutandus et accommodandus est (Cicero, Comment. pet. 42-43) 'Now, my brother, you have many wonderful qualities, but those you lack you must acquire and it must appear as if you were born with them. You have excellent manners and are always courteous, but you can be rather stiff at times. You desperately need to learn the art of flattery-a disgraceful thing in normal life but essential when you are running for office. If you use flattery to corrupt a man, there is no excuse for it, but if you apply ingratiation as a way to make political friends, it is acceptable. For a candidate must be a chameleon, adapting to each person he meets, changing his expression and speech as necessary' (text and translation Freeman 2012). I thank J. Hall for pointing me to this reference. 
Berger, Ł., (2016), 'Escenas de bienvenida en las comedias de Plauto', Scripta Classica 13, $65^{-84 .}$

Brown, P. \& Levinson, S.C., ( ${ }^{2} 1987$ [1978]), Politeness: some Universals in Language Usage, Cambridge.

Clackson, J., (2017), 'Adulatio', in P. Duarte, F. Fleck, P. Lecaudé, \& A. Morel (eds.), Histoires de mots. Études de linguistique latine et de linguistique générale offertes en hommage à Michèle Fruyt, Paris, 27-34.

Crampon, M., (1988), 'Le parasitus et son rex dans la comédie de Plaute: la revanche du langage sur la bassesse de la condition', in Y. Yogue \& M. Doi (eds.), Forms of Control and Subordination in Antiquity, Leiden/New York/Copenhagen/Cologne, 507522.

Culpeper, J., (2011), Impoliteness: Using Language to Cause Offence, Cambridge.

Damon, C., (1997), The Mask of the Parasite. A Pathology of Roman Patronage, Ann Arbour.

Davidson, J., (2004), Hypocrisy and the Politics of Politeness. Manners and Morals from Locke to Austen, Cambridge.

Dutsch, D.M., (2008), Feminine Discourse in Roman Comedy. On Echoes and Voices, Oxford.

Dutsch, D.M., (2012), 'Genre, Gender, and Suicide Threats in Roman Comedy', Classical World 105, 187-198.

Fedriani, C., (2017), 'Quaepropter, quaeso? “Why, for Pity's Sake?": Questions and the Pragmatic Functions of quaeso, obsecro and amabo in Plautus', in C. Denizot \& O. Spevak (eds.), Pragmatic Approaches to Latin and Ancient Greek, Amsterdam/Philadelphia, 83-109.

Ferri, R., (2012), 'How to Say No in Latin: Negative Turns, Politeness and Pragmatic Variation', in M. Leiwo, H. Halla-aho, \& M. Vierros (eds.), Variation and Change in Greek and Latin, Helsinki, $115^{-137 .}$

Fish, K., Rothermich, K., \& Pell, M.D., (2017), 'The Sound of (In)sincerity', Journal of Pragmatics 121, 147-161.

Filoche, C., (2014), 'La parole du parasite Plautinien ou l' espace ludique d' un personnage de bouffon', Revue des Études Latines 92, 21-33.

Fontaine, M., (2010), Funny Words in Plautine Comedy, Oxford.

Freeman, P., (2012), How to Win an Election: an Ancient Guide for Modern Politicians, Princeton/Oxford.

Goffman, E., (1959), The Presentation of the Self in Everyday Life, New York.

Guastella, G., (1988), La contaminazione e il parassita. Due studi su teatro e cultura romana, Pisa.

Guastella, G., (2002), 'I monologhi di ingresso dei parassiti: Plauto e i modelli', in C. Questa \& R. Raffaelli (eds.), Due seminari plautini, Urbino, 155-198.

Hall, J., (2009), Politeness and Politics in Cicero's Letters, Oxford/New York. 
Iurescia, F., (2016), 'Strategies of Persuasion in Provoked Quarrels in Plautus: a Pragmatic Perspective', in E. Sanders \& M. Johncock (eds.), Emotion and Persuasion in Classical Antiquity, Stuttgart, 281-294.

Iurescia, F., (2019a), Credo iam ut solet iurgabit: pragmatica della lite a Roma, Göttingen.

Iurescia, F., (2019b), 'How to Assess Politeness in Response to Impoliteness? Some Examples from Latin Comedy', in L. van Gils, C. Kroon, \& R. Risselada (eds.), Lemmata Linguistica Latina, vol. 2: Clause and Discourse, Berlin, 431-447.

Kaster, R.A., (2005), Emotion, Restraint and Community in Ancient Rome, Oxford/New York.

Konstan, D., (2018), 'Praise and Flattery in the Latin Epic: a Case of Intratextuality', in S. Harrison, S. Frangoulidis, \& T.D. Papanghelis (eds.), Intratextuality and Latin Literature, Berlin.

Leech, G., (2014), The Pragmatics of Politeness, Oxford.

Lowe, J.C.B., (1989), 'Plautus' Parasites and the Atellana', in G. Vogt-Spira (ed.), Studien zur vorliterarischen Periode im frühen Rom, Tübingen, 161-169.

Maltby, R., (2000), 'The Language of Plautus' Parasites', in L. Hardwick, P.E. Easterling, \& S. Ireland (eds.), Theatre: Ancient \& Modern, Milton Keynes, 32-45.

Melo, W. de, (2011-2013), Plautus, Comedies, 5 vols., Cambridge, Mass./London.

Mills, S., (2003), Gender and Politeness, Cambridge.

Paternoster, A., (2012), 'Inappropriate Inspectors: Impoliteness and Overpoliteness in Ian Rankin's and Andrea Camilleri's Crime Series', Language and Literature 21, 311324.

Petrone, G., (1989), 'Campi Curculionii, ovvero il bestiario del parassita (Plauto Mi. 13 ss.)', Studi Italiani di Filologia Classica 7, 34-55 (repr.: G. Petrone, Quando le Muse parlavano latino. Studi su Plauto, Bologna 2009, 43-66).

Pinto, D., (2011), 'Are Americans Insincere? Interactional Style and Politeness in Everyday America', Journal of Politeness Research 7, 215-238.

Roesch, S., (2019), 'Impoliteness in Plautus' comedies', in L. Van Gils, C. Kroon, \& R. Risselada (eds.), Lemmata Linguistica Latina, vol. 2: Clause and Discourse, Berlin, 413430.

Schulze, R., (1984), 'Manipulative Politeness: Speaker-Oriented Strategies in Persuasive Interaction', AILA Brussels 84 Proceedings 3, 1191-1192.

Sorlin, S., (2017), 'The Pragmatics of Manipulation: Exploiting Im/politeness Theories', Journal of Pragmatics 121, 132-146.

Stokke, A., (2014), 'Insincerity', Nô̂s 48, 496-520.

Stokke, A., (2018), Lying and Insincerity, Oxford/New York.

Talwar, V., Murphy, S.M., \& Lee, K., (2007), 'White Lie-Telling in Children for Politeness Purposes', International Journal of Behavioral Development 31, 1-11.

Unceta Gómez, L., (2015), 'Sobre el proceso de subjetivación de algunas formas verbales 
en la lengua de la comedia romana', in G. Haverling (ed.), Latin Linguistics in the Early 21st Century, Uppsala, 468-479

Unceta Gómez, L., (2016), 'Congratulations in Latin Comedy: Types and Functions', Journal of Politeness Research 12, 267-29o.

Unceta Gómez, L., (2018), 'Gli studi sulla (s)cortesia linguistica in latino. Possibilità di analisi e proposte per il futuro', Studi e Saggi Linguistici 56(2), 9-37.

Unceta Gómez, L., (2019a), 'Expressing Happiness as a Manifestation of Positive Politeness in Roman Comedy', in L. van Gils, C. Kroon, \& R. Risselada (eds.), Lemmata Linguistica Latina, vol. 2: Clause and Discourse, Berlin, 393-412.

Unceta Gómez, L., (2019b), 'I complimenti e il loro contributo all'espressione della cortesia linguistica nelle commedie di Plauto', Dionysus ex Machina 10, 283-311.

Unceta Gómez, L., (2019c), 'Conceptualizations of Linguistic Politeness in Latin: the Emic Perspective', Journal of Historical Pragmatics 20, 286-312.

Watts, R.J., (2003), Politeness, Cambridge. 